\title{
REVITALISASI KOMPETENSI PROFESIONALISME PENDIDIK \\ DI DALAM PENDIDIKAN AGAMA ISLAM
}

\section{Muchamad Agus Munir}

Akademisi Pendidikan agama Islam, Alumnus Pascasarjana UIN Sunan Kalijaga Yogyakarta. Ketua Penjaminan Mutu Pendidikan dan Guru Pendidikan Agama Islam di Yayasan AnNabawi Ays-Syarif Wonosobo.

email : siapamirat@gmail.com

\begin{abstract}
This research tries to reformulate the meaning rather than education professionalism in Islamic religious education. The problem that has arisen lately is that educators are only limited to teaching and teaching knowledge to students, and only aborting obligations as teaching professional workers, so it cannot be denied, the quality of educators in PAI is very low in professionalism. Whereas in the PAI the meaning of educators is not only limited to that when viewed in terms of professionalism. There are words of Murabbi, Mu'allim, Muaddib, Mudarris, ahl-Zikr, who have concerns about their individual upbringing patterns. In particular the government has issued a law relating to the professionalism of education personnel, except that in practice many of the educators do not comply with these regulations. The results of this study indicate that Islamic religious education needs to revitalize the professionalism of educators, through the reinterpretation of the concept of educators and combined with government regulations on professionalism. Educators need the creativity of the elements of education, mastery of students, and guidance so that students can develop their potential. Thus the professionalism of educators can be run well.
\end{abstract}

Keywords: Revitalization, Professionalism Competence, Educators, Islamic Education

\section{A. PENDAhuluan}

Salah satu unsur dalam pendidikan agama Islam yang penting adalah pendidik. Islam menyebut pendidik sebagai Murabbi, Mu'allim, Muaddib, Mudarris, ahl-Zikr (Nata, 1997, p. 61). Semuanya istilah tersebut mempunyai spesifikasinya tersendiri dalam memaknai 


\section{Muchamad Agus Munir}

tugas sebagai pendidik. Selain keistimewaan istilah tersebut, pendidik dalam pendidikan agama Islam juga banyak disinggung dalam al-Qur'an sebagai manusia yang mampu mengembangkan dan merawat alam semesta. Terkait dengan hal ini, pendidik diharuskan untuk dapat membentuk kepribadian, akhlak, dan pola pikir yang terdidik (anak didik). Dalam sejarah pendidikan agama Islam pendidik dicontohkan sebagai seorang yang mumpuni serta kuat pendalamannya dalam ilmu pengetahuan. Fazlurrahman menganalisis fenomena pendidik masa lalu sebagai seorang yang dapat member pemahaman yang mendalam bagi anak didik (Rahman, 2010, p. 243). Ia juga mengatakan bahwa sebelum adanya lemabaga pendidikan agama Islam, sosok pendidik memainkan peran sentral sebagai pengembang ilmu pengetahuan. Namun setelah adanya lembaga pendidikan peran pendidik mengalami penurunan dalam hal pengembangan keilmuan, seperti di lingkungan lembaga pendidikan Nizamiyyah. Lembaga pendidikan agama Islam pertama dalam lintasan sejarah lembaga tersebut semakin tertutup dalam pengembangan keilmuan. Fungsi pendidik hanya dijadikan konspirasi bagi tegaknya kekuasaan para penguasa dengan memasukkan berbagai doktrin agama. Yang paling menonjol barangkali pengkhususan bagi para pengajar dan anak didik untuk berpaham Sunni.

Pendidikan agama Islam akhirnya hanya dipandang sebagai proses mengahsilkan para ekstrimis-ekstrimis yang mempunyai pandangan sempit. Hal ini dikarenakan para pengajar dan pendidik lembaga Islam hanya mengajarkan keilmuan agama yang dinilai dapat menyelematkan manusia di akhirat nanti, sehingga melupakan keilmuan yang lain. Lebih ironisnya lagi, materi agama hanya diajarkan yang sifatnya praktis, tanpa menyentuh hal-hal yang substansial. Meskipun porsi agama lebih banyak, sangat disayangkan para pendidik mengajarkan materi-materi keagamaan hanya sebatas normative-tekstual. Dalam penelurusan Abdurrahman Assegaf, pola semacam ini hanya akan melahirkan kaum terpelajar yang bernalar deduktif-normatif (Assegaf, 2011, p. 22). Tidak berbeda jauh dengan yang terjadi di Indonesia. Sampai hari ini pendidik di lembaga pendidikan agama Islam masih saja terjebak dalam pola ajar keilmuan agama yang tidak mendalam. Sebagaimana yang diungkapkan Halili, bahwa tugas pokok guru direduksi menjadi subject matter delivery, agen pelaksana kurikulum formal (Halili, 2014, p. 25). Pendidik tidak lagi jadi ujung tombak pembangunan bangsa, tetapi alat kekuasaan rezim penguasa.

Selain permasalahan tersebut, Pendidik di lingkungan pendidikan agama Islam pada khusunya sedang mengalami pergeseran dan perubahan yang amat mendasar. Penggunaan sains dan tekhnologi di dalam proses pembelajaran, menyebabkan semakin mengecilnya peran dan fungsi pendidik, karena banyak tugas-tugas kependidikan terutama dalam transfer knowledge dan transfer value sudah tergantikan oleh tekhnologi. Demikian pula dimensi 
"sakralitas" dan "kekudusan" seorang pendidik semakin tergeser. Do'a dan nasihatnya kurang dinantikan, dan perannya tergeser pada fungsi-fungsi kebendaan yang bersifat mekanistik, seperti fungsi fasilitator, katalisator, dan mediator. Ditengah pergeseran visi dan misi pendidikan tersebut diperlukan sebuah formulasi. Agar dalam melaksanakan tugas dan peran kependidikan dapat menghasilkan para lulusan pendidikan agama Islam memiliki keunggulan dalam bidang fisik, intelektual, ketrampilan, moral, dan spiritual.

\section{B. PEMBAHASAN}

1. Makna Pendidik dalam Pendidikan Agama Islam

Pendidik merupakan sebuah elemen terpenting dalam pendidikan agama Islam. Pendidik mempunyai konotasi sebagai orang yang mempunyai derajat keilmuan yang tinggi. Dalam konteks pendidikan secara umum, tugas seorang pendidik dititiberatkan pada upaya untuk mengembangkan seluruh potensi peserta didik, baik potensi kognisi, psikomotor, maupun afeksi (Tafsir, 2008, p. 74). Dalam pedidikan Islam pendidikan diterjemahkan sebagai pihak yang bertanggung jawab terhadap perkembangan jasmani dan rohani peserta didik untuk mencapai tingkat kedewasaan, sehingga mereka memiliki bekal yang cukup dan mampu menjalankan tugas-tugas kemanusiaannya baik sebagai hamba maupun khalifah Allah di muka bumi berlandaskan nilai-nilai Islam (Nizar, 2002, p. 42).

Pendidikan agama Islam sendiri mempunyai konsep pendidik yang bermacammacam. Diantaranya adalah melalui kata $R a b b$, yang biasa diterjemahkan dengan "Tuhan" dan mengandung pengertian sebagai Tarbiyah (Hamruni, 2008, p. 55). Yang mempunyai arti menumbuh-kembangkan sesuatu secara bertahap sampai sempurna, dan pihak yang mendidik disebut dengan istilah Murabbi (Ash-Shiddiqiey, 1977, p. 12). Adapun kata Rabb yang menjadi kata kunci dalam konsep pendidik, di sebutkan dalam al-Qur'an sebanyak 744 kali (Sahil, 2007, p. 797).

Istilah pendidik berikutnya yang terdapat dalam al-Qur'an adalah al-Mu'allim (al-Ta'lim), yang berakar dari kata 'alima-ya'lamu dan 'allama-yu'allimu. Kata 'alima-ya'lamu berarti mengetahui,mengerti atau member tanda, sedangkan kata 'allama-yu'allimu memiliki makna mengajarkan, mengecap, atau member tanda. Istilah al-Mu'allim juga mempunyai konotasi khusus dalam pengertian "ilmu" (al'ilm), sehingga konsep al-mu' allim atau al-ta 'lim mempunyai "pengajaran ilmu”, atau menjadikan seorang berilmu (Dosen, 1996, p. 15-16). Istilah al-mu'allim yang seakar dengan kata 'alima-ya'lamu dan 'allama-yu'allimu dengan berbagai turunannya dalam al-Qur'an disebutkan sekitar 438 ayat (Sahil, 2007, p. 13-15). Istilah lain yang 


\section{Muchamad Agus Munir}

dijumpai dalam al-Qur'an tentang fungsi pendidik adalah ahl az-Zikr (Q.S. An-Nahl: 43). Dalam konteks ini, al-Qur'an menyeru manusia (umat Islam) untuk bertanya mengenai kebenaran kepada orang yang tepat dan otoritatis di bidangnya (ahl az$z i k r$ ), jika tidak mengetahui tentang sesuatu (Daud, 1998, p. 260). Melalui kata ini, al-Qur'an mengarahkan kepada setiap orang yang memiliki kapasitas dan etika keilmuan, pada hakikatnya mempunyai tanggung jawab untuk melakukan pendidikan atau berperan sebagai pendidik.

Melihat dari kata pendidik yang beragam di dalam al-Qur'an, perlu kiranya menulusuri konsepsi pendidik yang dipakai dalam pendidikan agama Islam/agama Islam. Kecenderungan pendidikan agama Islam selama ini memasukkan kata "Islam" di dalam kata "Pendidikan", namun dalam pelaksanaannya masih cenderung sama dengan pendidikan umum. Sama halnya dengan kata pendidik itu sendiri, belum ada konsepsi yang jelas mengenai pendidik. Hal itu dapat dilihat dari pengertian pendidik yang banyak dikemukakan oleh tokoh-tokoh pendidikan agama Islam. Ahmad D. Marimba beranggapan pendidik menyangkut tanggungjawab pengetahuan (Marimba, 1980, p. 12), Asy-Syaibani mendefinisikan pendidikan sebagai pembentuk kepribadian Islami terhadap peserta didik (Asy-Syaibani, 1979, p. 23), al-Attas lebih menekankan pendefinisian dalam hal etika dan adab atau kemajuan (kecerdasan, kebudayaan) lahir dan batin (Al-Attas, 1992, p. 7). Pemaknaan terhadap pendidik oleh para tokoh pendidikan belum mempunyai pondasi yang jelas. Dengan demikian pendidik dalam PAI wajar apabila belum bekerja secara profesional dalam menjalankan profesinya.

2. Antara Profesi dan Profesionalisme

Profesi pendidik/guru di wilayah pendidikan khususnya yang formal sangat diminati oleh banyak orang. Bahkan para orang tua sampai mengharapkan anaknya kelak menjadi seorang pendidik. Hal ini disebabkan karena posisi pendidik di dalam memajukan bangsa, serta pendidik menjadi ladang untuk meningkatkan kualitas ekonomi. Saiful Bahri Asmu'in menjelaskan guru dalam perspektif historis sebagai figure manusia yang nyaris tanpa cacat. Ia hadir sebagai manusia yang pandai, arif, bijaksana, sabar, jujur dan penuh pengabdian sehingga masyarakat menjadi segan, menaruh hormat dan menganggap sebagai sosok panutan yang berwibawa (Asmu'in, 1997, p. 27).

Tingginya prestise masyarakat terhadp seorang pendidik agama dapat kita saksikan sampai sekarang. Di lembaga pendidikan agama Islam khususnya Pesantren, para santri tidak akan berani menatap sinar mata kyainya, sebab tingginya ilmu yang ada di dalam dirinya. bahkan, ada santri yang tidak berani kencing menghadap rumah 
kyainya, sekalipun ia berada dalam kamar yang tertutup (Tafsir, 2013, p. 123). Para guru mendidik dengan ketulusan dan penuh pengabdian. Pemusatan mendidik hanya untuk subjek didik untuk mengusai pengetahuan yang diajarkan. Para pendidik menyadari dengan sadar bahwa anak didik adalah orang yang masih membutuhkan bimbingan. Dalam hal ini bimbingan diperlukan untuk membebaskan dari kebodohan dan keburukan. Peserta didik dianggap sebagai agen untuk merubah dirinya sendiri melalui ilmu pengetahuan yang telah didapatkan. Namun seirng dengan berjalannya waktu peserta didik mengalami missing link dengan pendidik.

Profesi mendidik bukan sebagai ajang kehidupan, pendidik mengalami perubahan dalam hal nilai dan pengetahuan. Nilai-nilai pragmatis mulai merasuki kehidupan pendidik sehingga tujuan mendidik bukan sebagai pengabdian. Menurut Sajjad Husain dan Ali Asyraf pendidik hanya dipandang sebagai petugas semata yang menerima gaji dari Negara atau lembaga swasta, dengan sederetan tanggung jawab tertentu yang harus diselesaikan. Sehingga mengakibatkan peserta didik kehilangan rasa hormat kepada guru sebagai figur yang patut untuk dicontoh dan ditauladani (Ashraf, 194, p. 153-154). Pengetahuan dikomersilkan untuk meraup keuntungan kekayaan pribadi. Hal itu berakibat pada posisi guru yang semakin merosot. Hubungan guru dengan murid semakin kurang bernilai kelangitan, penghargaan (penghormatan) anak didim terhadap guru semakin turun. Guru juga semakin mengikuti mainstream kekinian, karya-karya yang lahir dari kerja kerasnya hanya dipandang berharga apabila memiliki nilai jual.

Akhirnya posisi keguruan hanya dijadikan ajang untuk mencari kekayaan tanpa mempertimbangkan keberhasilan output pendidikan. Mutu lulusan yang diharapkan mampu berperan dalam kancah kehidupan, malahan menjadi manusia-manusia yang terdidik tetapi tidak mampu survive. Pengetahuan yang diajarkan kepada anak didik hanya sebatas kewajiban dalam sistem kependidikan, yang mana anak didik belum tentu memahaminya. Dalam konteks keIndonesiaan, banyak hal yang perlu dicermati dalam kerangka mutu profesionalisme guru. Apalagi umat Islam di Indonesia adalah fakta mayoritas umat. Karena itu, secara konsekuensional umat Islam Indonesia bertanggung jawab dan memiliki kontribusi besar atas perkembangan dan kemajuan Indonesia dalam semua aspek pembangunan, tak terkecuali dalam bidang pendidikan, khususnya mutu profesionalisme guru pendidikan agama Islam (PAI).

3. Dasar Profesionalisme Pendidik

Menurut Franz Magnis Suseno profesionalisme sebagai sikap "professional" atau "profi". Ia mengatakan menjadi "profi" yang merupakan idaman banyak 


\section{Muchamad Agus Munir}

orang muda zaman modern, terutama para mahasiswa yang sesudah ada kebijakan normalisasi kampus melepaskan idaman menjadi pemaharu masyarakat, suara hati bangsa, dan cita-cita profesional (Suseno, 1992, p. 196). Pengertian tersebut mengindikasikan bahwa profesionalisme merupakan usaha kelompok masyarakat untuk memperoleh pengawasan atas sumber daya yang berhubungan dengan pekerjaan tertentu. Umumnya dalam profesionalisme terdapat lima hal yang harus diperhatikan yaitu: pertama, menggunakan kelompok atau organisasi professional sebagai kelompok referensi utama, kedua, melayani masyarakat, ketiga memiliki kepedulian atau rasa terpanggil dalam bidangnya, keempat memiliki rasa otonomi, kelima mengatur dirinya sendiri (self-regulation) (Subro, 2011, p. 82).

Dalam Pasal 1 UU No 14 tahun 2005 tentang Guru dan Dosen (selanjutnya disingkat UUGD) disebutkan bahwa Guru adalah pendidik profesional dengan tugas utama mendidik, mengajar, membimbing, mengarahkan, melatih, menilai, dan mengevaluasi peserta didik pada pendidikan anak usia dini jalur pendidikan formal, pendidikan dasar, dan pendidikan menengah (UU No.14, 2005). Guru profesional sebagaimana dimaksud dalam pasal tersebut adalah pekerjaan atau kegiatan yang dilakukan oleh seseorang dan menjadi sumber penghasilan kehidupan yang memerlukan keahlian, kemahiran, atau kecakapan yang memenuhi standar mutu atau norma tertentu serta memerlukan pendidikan profesi (UU No. 14, 2005).

Menurut Oemar Hamalik, guru profesional, harus memiliki persyaratan yang meliputi: memiliki bakat sebagai guru, memiliki keahlian sebagai guru, memiliki keahlian yang baik dan terintegrasi, memiliki mental yang sehat, berbadan sehat, memiliki pengalaman dan pengetahuan yang luas, guru adalah manusia berjiwa pancasila, dan seorang warga negara yang baik (Oemar, 2001, p. 118). Apa yang disampaikan Oemar Hamalik tersebut, tidak jauh beda dengan pasal yang tercantum dalam UUD, pasal 8, 9, dan 10, sebagai berikut:

"Pasal 8: Guru wajib memiliki kualifikasi akademik, kompetensi, sertifikat pendidik, sehat jasmani dan rohani, serta memiliki kemampuan untuk mewujudkan tujuan pendidikan nasional.

Pasal 9: Kualifikasi akademik sebagaimana dimaksud dalam Pasal 8 diperoleh melalui pendidikan tinggi program sarjana atau program diploma empat.

Pasal 10: (1) Kompetensi guru sebagaimana dimaksud dalam Pasal 8 meliputi kompetensi pedagogik, kompetensi kepribadian, kompetensi sosial, dan kompetensi profesional yang diperoleh melalui pendidikan profesi." 


\section{el-'Tarbawj}

Kemudian dalam tugas keprofesionalannya, guru mempunyai tugas:

a. merencanakan pembelajaran, melaksanakan proses pembelajaran yang bermutu, serta menilai dan mengevaluasi hasil pembelajaran;

b. meningkatkan dan mengembangkan kualifikasi akademik dan kompetensi secara berkelanjutan sejalan dengan perkembangan ilmu pengetahuan, teknologi, dan seni;

c. bertindak objektif dan tidak diskriminatif atas dasar pertimbangan jenis kelamin, agama, suku, ras, dan kondisi fisik tertentu, atau latar belakang keluarga, dan status sosial ekonomi peserta didik dalam pembelajaran;

d. menjunjung tinggi peraturan perundang-undangan, hukum, dan kode etik guru, serta nilai-nilai agama dan etika; dan

e. memelihara dan memupuk persatuan dan kesatuan bangsa. (UU No.14, 2005)

Undang-undang nomor 20 tahun 2003 tentang Sistem Pendidikan Nasional, undang-undang nomor 14 tahun 2005 tentang Guru dan Dosen, dan Peraturan PemerintahNomor 19 tahun2005 tentang Standar Nasional Pendidikanmengamanatkan bahwa guru adalah pendidik profesional. Seorang guru atau pendidik profesional harus memiliki kualifikasi akademik minimum sarjana (S1) atau diploma empat (D4), menguasai kompetensi (pedagogik, profesional, sosial, dan kepribadian), memiliki sertifikat pendidik, sehat jasmani dan rohani, serta memiliki kemampuan untuk mewujudkan tujuan pendidikan nasional. Yang dimaksud kompetensi profesional adalah kemampuan penguasaan materi pelajaran secara luas dan mendalam (Niiam, 2006, p. 199).

Seorang pendidik profesional selalu menginginkan umpan balik atas proses pembelajaran yang dilakukannya. Hal tersebut dilakukan karena salah satu indikator keberhasilan pembelajaran ditentukan oleh tingkat keberhasilan yang dicapai peserta didik. Dengan demikian, hasil penilaian dapat dijadikan tolok ukur keberhasilan proses pembelajaran dan umpan balik bagi pendidik untuk meningkatkan kualitas proses pembelajaran yang dilakukan. Adanya komponenkomponen yang menunjukkan kualitas mengevaluasi akan lebih memudahkan para guru untuk terus meningkatkan kualitas menilainya. Dengan demikian, berarti bahwa setiap guru memungkinkan untuk dapat memiliki kompetensi menilai secara baik dan menjadi guru yang bermutu (Kunandar, 2007, p. 66):

a. Mempelajari fungsi penilaian

b. Mempelajari bermacam-macam teknik dan prosedur penilaian

c. Menyusun teknik dan prosedur penilaian 


\section{Muchamad Agus Munir}

d. Mempelajari kriteria penilaian teknik dan proseur penialaian

e. Menggunakan teknik dan dan prosedur penilaian

f. mengolah dan menginterpretasikan hasil penilaian

g. menggunakan hasil penilaian untuk perbaikan proses belajar mengajar

h. menilai teknik dan prosedur penilaian

i. menilai keefektifan program pengajaran

Pendidik yang memegang profesionalisme harus mengacu pada lima hal dasar, yaitu (Danim, 2012, p. 208):

a. Kemampuan pendidik dalam berpikir persepsional-rasional

b. Kemampuan berpikir kreatif-imajinatif

c. Kemampuan berpikir kritikal-argumentatif

d. Kemampuan memilih dari sejumlah alternative yang ada

e. Kemampuan berkehendak secara bebas

4. Revitalisasi Profesionalisme Pendidik di Lingkungan Pendidikan Agama Islam

a. Mengajar Sebagai Kegiatan Profesional

Menurut Deborah Court yang dikutip Sudarman Danim mengatakan,

“Di masa depan siswa dan generasi muda kontemporer, seperti halnya orang dewasa, akan menghadapi tekanan atau presi yang dahsyat, dimana hal itu menjadi masalah global yang memerlukan pemecahan. Tekanan itu muncul karena gelar kesarjanaan tidak lagi mampu menjadi garansi untuk mendapatkan pekerjaan yang sesuai, persaingan semakin ketat, kemajuan ilmu pengetahuan dan tekhnologi semakin canggih dan cepat,keunggulan kompetitif makin dituntut, SDA makin langka" (Danim, 2012, p. 213).

Artinya, peran sentral guru/pendidik dalam membelajarkan ilmu pengetahuan dituntut untuk bersikap professional. Tidak hanya yang sifatnya normative, seperti pengajaran dasar-dasar keagamaan, melainkan harus menyentuh ketrampilan dan kedalam pengetahuan. Kemampuan tersebut harus dimiliki guru agar mampu merespon tantangan zaman dan memberitahukan kepada anak didik persiapan-kesiapan yang harus dimiliki.

Di dalam pendidikan agama Islam yang notabene sebagai pendidikan keagamaan, selama ini mutu lulusan pendidiknya masih kurang berkualitas. Indikator berkualitas atau tidak pendidik sekarang ditentukan oleh beberapa hal diantaranya sanggup berperan atau bahkan merebut pasar, sanggup 
berinovasi dengan panduan dasar keilmiahan, serta mampu memjadikan anak didik mempunyai kualitas personal yang mumpuni. Maka dari itu, diperlukan sebuah formulasi baru terhadap jiwa keprofesionalan pendidik di dalam lembaga pendidikan agama Islam, agar dapat mencetak manusia-manusia yang sanggup untuk bergerak di kancah kehidupan global.

Reformulasi konsep pendidik yang meliputi mu'allim, muzakki, murabbi, dan sebagainya sudah menjadi kewajiban di dalam sistem pendidikan agama Islam agar profesi pendidik/guru tidak salah digunakan. Profesi pendidik merupakan tugas kemanusiaan yang didalamnya mencakup mendidik, mengajar, melatih, membersihkan, dan membentuk (Usman, 2002, p. 15). Tugas kemanusiaan tersebut, menuntut adanya pendidik yang tidak hanya berwawasan luas dan mendalam melainkan juga harus mempunyai komitmen bahwa perkerjaan mendidik berupa pengabdian ketulusan dari dalam diri sendiri.

Pendapat Imam al-Ghazali tentang profesi pendidik sebagaimana yang dikonsepsikan oleh M. Jawwad Ridha lebih bersifat "idealistik", artinya guru adalah orang yang berilmu, beramal dan mengajar. Lebih lanjut dikatakan profesi tersebut ada untuk orang yang "bergelut" dengan sesuatu yang amat wigati (penting), sehingga ia perlu menjaga etiket dank ode etik profesinya (Ridha, 2002, p. 129). Dengan demikian, profesi pendidik harus terlebih dahulu berangkat dari gerak-geriknya terlebih dahulu.

Mohammad Abduhzen dalam salah satu artikelnya menyoroti kesalahpemaknaan pendidik saat ini yang masih terjebak dalam makna profesionalisme yang materialistik: tunjangan profesi, sehingga pendidik mengalami kegagalan dalam mencapai tujuan utama keprofesionalisme, yaitu meningkatkan kinerja untuk peningkatan mutu pendidikan (Abduhzen, 2013). Memang sudah menjadi nalar umum bahwa pendidi/guru era sekarang mempunyai motif kinerja untuk mengahasilkan taraf ekonomis yang tinggi. Apalagi sejak terbitnya UU guru dan dosen tahun 2005, banyak peminat berbondong-bondong menjadi guru. Tetapi sejak terbitnya UU tersebut Indonesia masih kekurangan sumber daya guru yang berkualitas dan professional. Untuk itu, diperlukan penyadaran lebih lanjut menenai tugas dasar guru.

Makna profesi keguruan sangat besar dan mendalam, di dalam al-Qur'an ada ayat yang secara khusus menyebut tugas yang harus diemban oleh seorang guru, melalui penggambaran Rasullah SAW. Surat Ali Imran : 164, yang dijelaskan oleh Abdurrahman An-Nahlawi mempunya dua tugas keprofesian 


\section{Muchamad Agus Munir}

yaitu (An-Nahlawi, 1996, p. 170):

1) Penyucian, artinya seorang guru sebagai seorang pembersih diri, pemelihara diri, pengembang, serta pemelihara fitrah.

2) Pengajaran, artinya guru sebagai seorang penyampai ilmu pengetahuan dan berbagai keyakinan kepada manusia agar mereka menerapkan seluruh pengetahuannya dalam kehidupan sehari-hari.

b. Kreatif dan Transformatif

Profesionalisme pendidik yang mempunyai pengertian penguasaan kedalam pengetahuan, menuntut adanya subjek profesi mempunyai daya jelajah yang luas. Dibutuhkan kekreatifan pendidik untuk mengembangkan setiap materi yang akan diajarkan, agar anak didik tidak terjebak dalam pola pikir yang sempit. Hal ini senada dengan pengertian pendidik menurut Ikhwan as-Shafa, yang mensyaratkan kecerdasan, kedewasaan, kelurusan moral, ketulusan hati, kejernihan pikiran, etos keilmuan, dan tidak fanatik buta pada diri pendidik (Ridha, 2002, p. 169).

Perlunya meningkatkan kekreatifan, agar tugas mendidik bukan hanya kewajiban formalitas semata. Menurut Hamruni ada lima pokok tentang kreatifitas yang harus dimiliki pendidik antara lain (Hamruni, 2008, p. 87):

1) Penguasaan materi-materi Islam yang komprehensif serta wawasan dan bahan pengayaan, terutama bidang-bidang yang menjadi tugasnya

2) Penguasaan strategi (mencakup pendekatan, metode, dan tekhnik), pendidikan agama Islam, termasuk kemampuan evaluasinya.

3) Penguasaan ilmu dan wawasan kependidikan

4) Memahami prinsip-prinsip dan menafsirkan hasil penelitian pendidikan pada umumnya guna keperluan pengembangan pendidikan agama Islam.

5) Memiliki kepekaan terhadap informasi secara langsung atau tidak langsung yang mendukung kepentingan tugasnya.

Sebagai pendidik profesional, pengembangan setiap komponen diatas, diharapkan mampu untuk dimunculkan dalam setiap tindakan pendidik, baik di dalam kelas maupun di luar kelas. Kreatifitas pendidik akan mampu mendatangkan perubahan. Mengubah paradigma lama menuju paradigma baru dalam melakukan pembelajaran adalah sebuah tuntutan bukan tawaran. Eksistensi guru sebagai pendidik itu ada justru karena perubahan itu sendiri sehingga Keprofesionalan diwujudkan dalam tindakan nyata yang memiliki kesadaran transformatif 
menyadari adanya muatan, konsekuensi, dalam semua aktifitas pendidikan dan pengajaran. Cara pendidik mengajar, pilihan pengetahuan yang diajarkan berkontribusi dalam mebentuk subjektifitas peserta didik, baik mereka menjadi aktif maupun pasif.

Dengan mempertimbangkan perubahan pada peserta didik, maka pendidik yang kreatif juga termasuk dalam pendidik yang transformatif. Pendidik transformative dapat diartikan sebagai seorang yang berkesadaran (conscious being), bukan orang yang mempunyai kesadaran, atau prise de conscience, yang mampu memahami kehidupan sekitar (Nuryatno, 2011, p. 88). Pendidik transformatif selalu menekankan bahwa segala sesuatu yang ada di dunia bukan bersifat "pemberian", melainkan kehidupan di dunia sebagai ajang untuk “menjadi”. Lebih lanjut M. Agus Nuryatno menyebutkan kriteria-kriteria pendidik transformative, diantaranya (Nuryatno, 2011, p. 87-89):

1) Mengarahkan peserta didik memperoleh tingkat ketrampilan kognitif yang tinggi agar dapat menguasai ketrampilan-ketrampilan teknis yang diperlukan dalam dunia kerja.

2) Pendidikan bukan sebagai reproductive force, tapi sebagai productive force yaitu sebagai mobilitas sosial.

3) Pendidik meyakini kemampuan peserta didik untuk berpartisipasi dalam penciptaan sejarah manusia.

4) Pendidik senantiasa menghadapkan teks-teks normatif yang tertuang dalam kurikulum dengan realitas sosial yang terjadi di luar kelas.

5) Pendidik memandang perlunya dikembangkan language of critique dan language of possibility.

\section{PENUTUP}

Pendidik sebagai agen perubahan bagi peserta didik, sudah seharusnya dapat memaksimalkan profesinya. Profesi yang sejak terbitnya UU guru dan dosen tahun 2015 harus dimaknai sebagai reward atas kerasnya dalam mencerdaskan bangsa. Bukan malah sebaliknya, pendidik hanya memikirkan kompensasi keprofesian dengan mengabaikan kewajibannya mendidik, mengajar, dan membentuk peserta didik. Pendidikan agama Islam mempunyai nomenklaturnya tersendiri mengenai konsepsi pendidik, sebagaimana yang tercermin dalam kata murabbi, mu'allim, muzakki, ulama', ulul albab, dan ahl-zikr. Makna profesi pendidik yang diambil dari kata-kata tersebut semakna dengan definisi pendidik dalam UU Sisdiknas tahun 2003. 


\section{Muchamad Agus Munir}

Dengan disahkannya pendidik sebagai tenaga profesi, maka tuntutan dalam pekerjaannya tidak hanya mengajar dan mendidik. Namun lebih jauh dari itu pendidik diharuskan merangsang ruang gerak peserta didik untuk mengembangkan serta memahami lebih jauh. Sebab saat ini di dalam lembaga pendidikan banyak kesalahartian mengenai tugas mengajar hanya sebatas pelaksanaan kewajiban semata, tanpa memperhatikan perkembangan peserta didiknya. Realitas kehidupan yang semakin berkembang, menuntut adanya pendidik yang mempunyai wawasan dan kedalam pengetahuan, yang sanggup melewati batas-batas kenormatifan.

Pertimbangan-pertimbangan tersebut memberikan isyarat agar pendidik lebih mampu mengembangkan kreatifitas serta transformataif. Kreatifitas yang diperlukan oleh pendidik tidak hanya dalam penguasaan materi, melainkan mencakup unsure-unsur dalam proses pembelajaran seperti metode, strategi, materi, tujuan, dan sebagainya. Khusus dalam materi dan strategi diperlukan penyesuaian terhadap realitas kehidupan yang semakin kompleks. Makna inilah yang kemudian ditafsirkan sebagai pendidik yang mempunyai daya transformasi yang tinggi. 


\section{Daftar Pustaka}

Abduhzen, Mohammad. Selasa, 2 Juni 2013. “Guru Generasi Baru”. Kompas.

Al-Attas, Syed Muhammad Naquib. (1992). Konsep Pendidikan dalam Islam. Bandung: Mizan.

An-Nahlawi, Abdurrahman. (1996) Pendidikan Islam di Rumah, Sekolah, dan Masyarakat. Terj. Sihabbudin. Jakarta: Gema Insani Press.

Ashraf, Syed Sajjad Husain dan Syed Ali. (1994). Menyongsong Keruntuhan Pendidikan Islam. Bandung: Gema Risalah Press.

Assegaf, Abdurrahman. (2011). Filsafat Pendidikan Islam. Jakarta: Rajawali.

Asmu’in, Saiful Bahri. (1997). “Menghargai Profesi Guru”. Rindang. No. 8. Th XXII.

Asy-Shiddieqy, TM. Hasbi. (1977). Tafsir al-Bayan. Bandung: al-Ma'arif.

Asy-Syaibany, M. Omar al-Toumy. (1979). Falsafah Pendidikan Islam, terj. Hasan Langgulung. Jakarta: Bulan Bintang.

Bukhori, Mochtar. (1994). Pendidikan dalam Pembangunan. Jakarta: IKIP Muhammadiyah Press.

Danim, Sudarman. (2012). Pengembangan Profesi Guru, dari Pra-jabatan Induksi ke Profesional Madani. Jakarta: Kencana.

Daud, Wan Mohd. (1998). Nor Wan. Filsafat dan Praktik Pendidikan Islam Syed M. Naquib alAttas. Bandung: Mizan.

Hamruni. (2008). Konsep Edutaintment dalam Pendidikan Islam. Yogyakarta: Suka Press.

Kunandar. (2007). Guru Profesional: Implementasi Kurikulum Tingkat Satuan Pendidkan Dan Sukses Dalam Sertifikasi Guru. Jakarta: Raja Grafindo Persada.

Marimba, Ahmad D. (1980). Pengantar Filsafat Pendidikan Islam. Bandung: N.V. Al-Ma'arif.

Nizar, Ramayulis dan Samsul. (2009). Filsafat Pendidikan Islam: Telaah sistem Pendidikan dan Pemikiran Para Tokohnya. Jakarta : Kalam Mulia.

Nuryatno, M. Agus. (2011). Mazhab Pendidikan Kritis menyingkap Relasi Pengetahuan Politik dan Kekuasaan. Yogyakarta: Resist Book.

Ridha, Muhammad Jawwad. (2002). Tiga Aliran Utama Teori Pendidikan Islam, Perspektif 
Sosiologi-Filosofis. Terj. Mahmud Arif. Yogyakarta: Tiara Wacana.

Sahil, Azharuddin. (2007). Indeks Al-Qur'an Panduan Mudah Mencari Ayat dan Kata dalam AlQur'an. Bandung: Mizan.

Shihab, Quraish. (2002). Tafsir Al-Misbah, vol. 1. Jakarta: Lentera Hati.

Sobur, Alex. (2001). Etika Pers Profesionalisme Dengan Nurani. Bandung: Humaniora Utama Press.

Suseno, Franz Magnis. (1992). Berfilsafat dari Konteks. Yogyakarta: Kanisius.

Tafsir, Ahmad. (2008). Ilmu Pendidikan Islami. Bandung: PT. Remaja Rosdakarya.

Tedjosaputro, Liliana. (1995). Etika Profesi Notaris dalam Penegakan Hukum Pidana. Yogyakarta: Bigraf Publishing.

Undang-Undang, No. 14, Tahun 2015, Tentang Guru dan Dosen.

Usman, M. Uzer. (2002). Menjadi Guru Profesional. Bandung: Remaja Rosdakarya. 